\title{
Synthesis, Crystal Structure and Photochemical Study of Bis(2,4,6-triphenylpyryllium)hexamolybdate (TPPM) and $\left[n-\mathrm{Bu}_{4} \mathrm{~N}\right]_{2}\left[\mathrm{Mo}_{6} \mathrm{O}_{19}\right] \cdot(\mathrm{TBAM})$
}

\author{
Xue-Xiang $\mathrm{Xu}^{\dagger, \mathrm{a}}$ Xiao-Zeng You, ${ }^{*, a}$ and Xin Wang*,b
}

\begin{abstract}
${ }^{a}$ Coordination Chemistry Institute, Sate Key Laboratory of Coordination Chemistry, Nanjing University, Centre for Advanced Studies in Science and Technology of Microstructures, Nanjing 210093 , People's Republic of China and ${ }^{b}$ Centre of Analysis Research, Lanzhou University, Lanzhou 730000, People's Republic of China
\end{abstract}

\begin{abstract}
Xu, X.-X., You, X.-Z., Wang, X., 1996. Synthesis, Crystal Structure and Photochemical Study of Bis(2,4,6-triphenylpyryllium)hexamolybdate (TPPM) and $\left[n-\mathrm{Bu}_{4} \mathrm{~N}\right]_{2}\left[\mathrm{Mo}_{6} \mathrm{O}_{19}\right] \cdot(\mathrm{TBAM})$. - Acta Chem. Scand. 50: 1-5 @ Acta Chemica Scandinavica 1996.

A complex between an organic photosensitizer, TPP, and the isopolyanion $\mathrm{Mo}_{6} \mathrm{O}_{19}{ }^{2-}$, of stoicheiometry (TPP) ${ }_{2} \mathrm{Mo}_{6} \mathrm{O}_{19}$ (TPPM), has been characterized in solution. The irradiation of the low-energy absorption bands of TPPM in solution results in immediate photochromism, a process which is reversible and repeatable. $\mathrm{Mo}_{6} \mathrm{O}_{19}{ }^{2-}$ can quench the fluorescence of TPP. Comparison of the photochromism of both TPPM and $\left[n-\mathrm{Bu}_{4} \mathrm{~N}\right]_{2}\left[\mathrm{Mo}_{6} \mathrm{O}_{19}\right]$ (TBAM) show that TPPM has more intense photochromism and a faster fade rate than that of TBAM. The photochromism process of TBAM is irreversible. In the crystal stack TPP cations form a stack, and the $\mathrm{Mo}_{6} \mathrm{O}_{19}$ anions form parallel columns alternately.
\end{abstract}

Recent work has highlighted the ability for photochromism of well known polyoxoanions conjugated with organic molecules. ${ }^{1-7}$ However, photochromism involving these compounds is not truly reversible. In order to prepare reversible photochromic materials, we have chosen photosensitive organic molecules as donor and Type I polyoxometalate anions having easily reduced properties $^{8}$ as acceptor. Such anions are still of interest because of their high electron acceptor capability. ${ }^{9}$ We report here a new reversible photochromic charge-transfer salt using photosensitive triphenylpyryllium (TPP) as donor and the hexamolybdate dianion $\left(\mathrm{Mo}_{6} \mathrm{O}_{19}{ }^{2-}\right)$, having the Lindquist structure, as acceptor. ${ }^{10}$ Although the photochemistry of $\left[n-\mathrm{Bu}_{4} \mathrm{~N}\right]_{2}\left[\mathrm{Mo}_{6} \mathrm{O}_{19}\right]$ (TBAM) under flash photolysis has been published previously, ${ }^{11}$ no photochromism has been reported under ultraviolet irradiation. In this paper the photochromism of TBAM in DMF solution is examined and compared with that of TPPM.

\section{Experimental}

All materials were of reagent grade and used without further purification. $\left[n-\mathrm{Bu}_{4} \mathrm{~N}\right]_{2}\left[\mathrm{Mo}_{6} \mathrm{O}_{19}\right]^{12}$ and $\mathrm{TPPClO}_{4}{ }^{13}$

\footnotetext{
† Present address: Institute of Chemistry, Academia Sinica, Beijing 100080, People's Republic of China.

* To whom correspondence should be addressed.
}

were prepared and purified according to literature procedures.

Elemental analyses were performed on a Perkin-Elmer $240 \mathrm{C}$ instrument. Electronic spectra were recorded on a Shimadzu UV-3100. The ESR spectra were obtained on a Bruker ER 200D spectrometer. The emission spectra were obtained using a RF-450 spectrofluorometer (Shanghai, China).

Synthesis of $[\mathrm{TPP}]_{2}\left[\mathrm{Mo}_{6} \mathrm{O}_{19}\right]$ (TPPM). The title compound has been obtained as a yellow precipitate by reacting a stoicheiometric amount of $\left[n-\mathrm{Bu}_{4} \mathrm{~N}\right]_{2}\left[\mathrm{Mo}_{6} \mathrm{O}_{19}\right]$ with (TPP) $\mathrm{ClO}_{4}$ in acetonitrile solution. Single crystals were obtained by a diffusion method. Anal: Calcd. for $\mathrm{C}_{46} \mathrm{H}_{34} \mathrm{Mo}_{6} \mathrm{O}_{21}: \mathrm{C}, 36.87 ; \mathrm{H}, 2.29$. Found: $\mathrm{C}, 36.65 ; \mathrm{H}$, 2.13 .

Determination of the crystal structure. A single crystal with the approximate dimensions $0.40 \times 0.25 \times 0.30 \mathrm{~mm}$ was mounted on a glass fibre. All the intensity data were collected on an Enraf-Nonius CAD4 diffractometer using graphite-monochromated $\mathrm{Cu} \mathrm{K} \alpha$ radiation $(\lambda=1.5418 \AA)$ with a scan mode of $\omega-2 \Theta$. Independent reflections (3578) were collected in the range $2<2 \Theta<116^{\circ}$, and 2598 reflections with $I>3 \sigma(I)$ were used for further computation. All data were corrected for Lorentz and polarization effects, and empirical absorption corrections, based on $\psi$ scans, were applied. 
TPPM is monoclinic, space group $C 2 / c, M_{\mathrm{r}}=1498.5$, with the cell dimensions $a=19.769(2), b=14.352(3)$, $c=16.868(2) \AA, \quad \beta=99.99(3)^{\circ}, \quad V=4713.4 \AA^{3}, \quad Z=4$, $D_{\text {calc }}=2.111 \mathrm{~g} \mathrm{~cm}^{-3}, F(000)=2920, \mu=136.8 \mathrm{~cm}^{-1}$. The structure analysis was performed on a PDP 11/44 computer with an SDP program. ${ }^{14}$ The positions of all the molybdenum atoms were determined by direct methods. The positions of other non-hydrogen atoms were revealed by difference Fourier syntheses. The hydrogen atoms, located in a difference map and fixed with isotropic $B=5.0 \AA^{2}$, were included as a fixed contribution. The structure was refined with unit weights by full-matrix least-squares methods with anisotropic thermal factors for all non-hydrogen atoms. Refinement converged to a final $R=0.078$ and $R_{\mathrm{w}}=0.079$ for the 2598 observed reflections.

\section{Results and discussion}

Synthesis of TPPM. When an acetonitrile solution of the $\mathrm{TPPClO}_{4}$ and isopolyoxomolybdate $\mathrm{Mo}_{6} \mathrm{O}_{19}{ }^{2-}$ are mixed, a new material far less soluble in acetonitrile than either of the components precipitates from the solution. This complex between the isopolymolybdate and the organic substrate, $\mathrm{TPP}_{2}\left[\mathrm{Mo}_{6} \mathrm{O}_{19}\right]$ (TPPM), can be recrystallized from DMF.

Photochemistry of TBAM and TPPM in solution. Figure 1 shows the absorption spectra of a DMF solution of TBAM before dianion formation, after $60 \mathrm{~min}$ of irradiation of the above solution, and after the solution had faded. On irradiation, the DMF solution of TBAM shows broad absorption bands at 660 and $820 \mathrm{~nm}$ in electronic

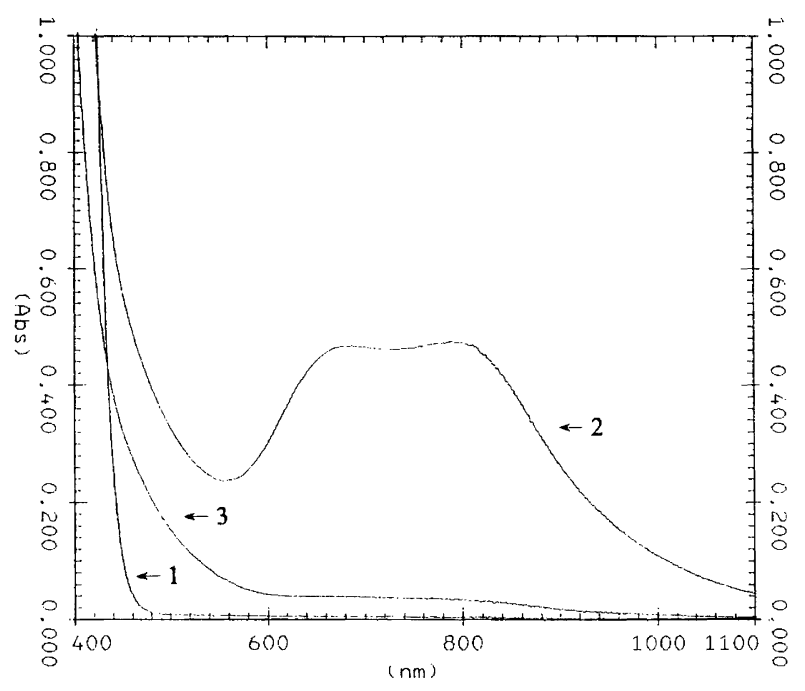

Fig. 1. Absorption spectra of $\left[n-\mathrm{Bu}_{4} \mathrm{~N}\right]_{2}\left[\mathrm{Mo}_{6} \mathrm{O}_{19}\right]$ (in DMF, $5{ }_{4} \times 10^{-3} \mathrm{M}$ ) in a $10 \mathrm{~mm}$ cell at room temperature, irradiation with a $500 \mathrm{~W}$ Xe lamp using cut-off filters $\geq 300 \mathrm{~nm}$ for $60 \mathrm{~min}$, (1) before irradiation, (2) after irradiation, and (3) after fade. spectra, which indicate that $\mathrm{Mo}^{\mathrm{V}} \mathrm{Mo}_{5}{ }^{\mathrm{VI}} \mathrm{O}_{19}{ }^{3-}$ were formed. The absorption spectrum of $\mathrm{Mo}^{\mathrm{v}}$ obtained in this work is very different in shape and peak position from that of produced by electrolysis of $\mathrm{Mo}_{6} \mathrm{O}_{19}{ }^{2-}$ in DMF. ${ }^{12}$ The band at $820 \mathrm{~nm}$ is assigned to the ${ }^{2} \mathrm{~B}_{2} \rightarrow{ }^{2} \mathrm{E}$ IVCT transitions (band B). ${ }^{10,12}$ In the electrolysis spectrum $\mathrm{Mo}^{\mathrm{V}}$ shows an IVCT transition of shoulder band $\mathrm{A}$ at $1110 \mathrm{~nm},{ }^{12}$ but has no band in the photochemical reduced $\mathrm{Mo}^{\mathrm{V}}$. This indicates that band A may have merged with band $\mathrm{B} .^{10}$ This case also occurred in other polyoxometalates on photochemical reduction. ${ }^{1,4}$ The band at $660 \mathrm{~nm}$ may also be ascribed to band $\mathrm{B}$, which did not occur in the spectrum of electroreduced $\mathrm{Mo}^{\mathrm{V}},{ }^{12}$ but was observed in the spectrum of photoreduced $\left[\mathrm{Mo}_{7} \mathrm{O}_{24}\right]^{6-}$. The colored solution shows a two-stage transient decay of the photochromer, and its first-order fade rate constants $k_{1}$ and $k_{2}$ are $1.8 \times 10^{-4}$ and $3.1 \times 10^{-5} \mathrm{~s}^{-1}$, respectively, by spectroscopic methods. The colored solution gave rise to a single intense ESR signal at $293 \mathrm{~K}$ $(g=1.923, \Delta H=52 \mathrm{G})$ due to $\mathrm{Mo}^{\mathrm{v}} .{ }^{12}$ TBAM was not equivalent to that obtained prior to photolysis; the maximum absorption shifted from 327 to $295 \mathrm{~nm}$ owing to photochemically induced changes. This implies that certain $\mathrm{Mo}^{\mathrm{V}}$ species or a protonated polyoxometalate ${ }^{\mathrm{b}}$ may exist in the faded solution. The primary photochemical reactions can be expressed as follows: ${ }^{11}$

$$
\begin{aligned}
& \mathrm{Mo}_{6} \mathrm{O}_{19}{ }^{2-} \stackrel{h v}{\rightleftharpoons}\left(\mathrm{Mo}_{6} \mathrm{O}_{19}{ }^{2-}\right)^{*} \\
& \left(\mathrm{Mo}_{6} \mathrm{O}_{19}{ }^{2-}\right)^{*}+\mathrm{SH}_{2} \rightleftharpoons \mathrm{Mo}_{6} \mathrm{O}_{19}{ }^{3-}+\cdot \mathrm{SH}+\mathrm{H}^{+}
\end{aligned}
$$

or

$$
\left(\mathrm{Mo}_{6} \mathrm{O}_{19}{ }^{2-}\right)^{*}+\mathrm{SH}_{2} \rightleftharpoons \mathrm{HMo}^{\mathrm{v}} \mathrm{Mo}_{5} \mathrm{O}_{19}{ }^{2-}+\cdot \mathrm{SH}
$$

where $\mathrm{SH}_{2}$ and $\cdot \mathrm{SH}$ represent DMF and $\mathrm{HCON}\left(\mathrm{CH}_{3}\right) \mathrm{CH}_{2}$, respectively. The $\cdot \mathrm{SH}$ radical may disappear by radical recombinant or self-decomposition. ${ }^{15}$ Because of the low quantum yield of $\mathrm{Mo}^{\mathrm{V}},{ }^{11}$ photochromism of TBAM has not been observed in $\mathrm{CH}_{3} \mathrm{CN}$ solution under ultraviolet light irradiation.

Figure 2 shows the electronic absorption spectra of TPP and TPPM before and after irradiation. On irradiation, although TPP exhibits photochromism with a maximum absorption band at $483 \mathrm{~nm}$, the TPPM displays more intense photochromism. The absorption spectrum of irradiated TPPM is very similar to that of TBAM, but its photochromism is more intense than that of the latter. The of photochromism of TPPM is reversible and can be repeated many times, but it fades away faster than TBAM; the rate constants are $k_{1}=3.8 \times 10^{-3}$ and $k_{2}=5.2 \times 10^{-5}$, respectively. In the resulting colored solution no ESR signal could be observed.

Figure 3 shows the fluorescence spectra of TPP and TPPM. The TPP exhibits intense fluorescence $\left(\lambda_{\max }=475 \mathrm{~nm}\right),{ }^{16}$ but the fluorescence intensity of TPPM is only $45 \%$ that of TPP. This indicates that the 


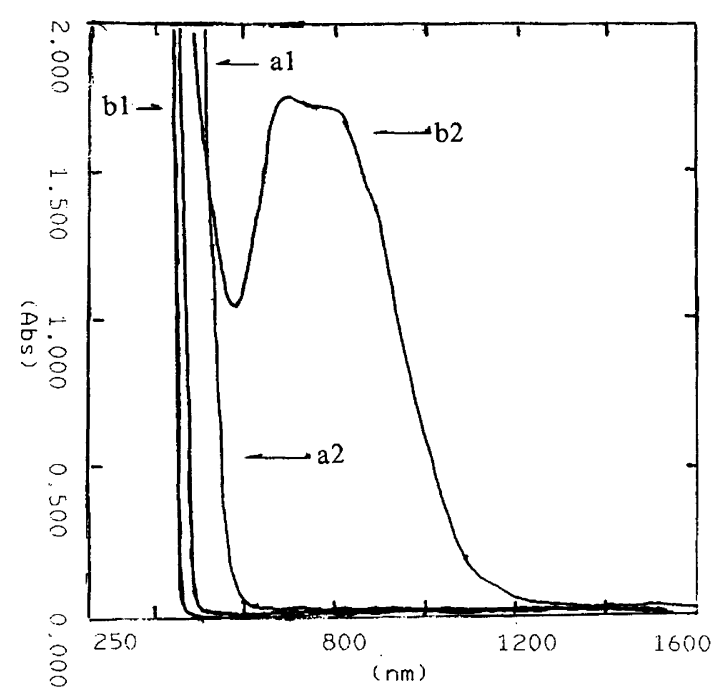

Fig. 2. Solution electronic spectra of the $\left(\mathrm{TPP}^{\mathrm{C}} \mathrm{CIO}_{4}\right.$ (a) and the title complex TPPM (b). Both $5 \times 10^{-3} \mathrm{M}$ (DMF). The condition of irradiation is the same as that of $\left[n-\mathrm{Bu}_{4} \mathrm{~N}\right]_{2}\left[\mathrm{Mo}_{6} \mathrm{O}_{19}\right],(1)$ before and (2) after irradiation.

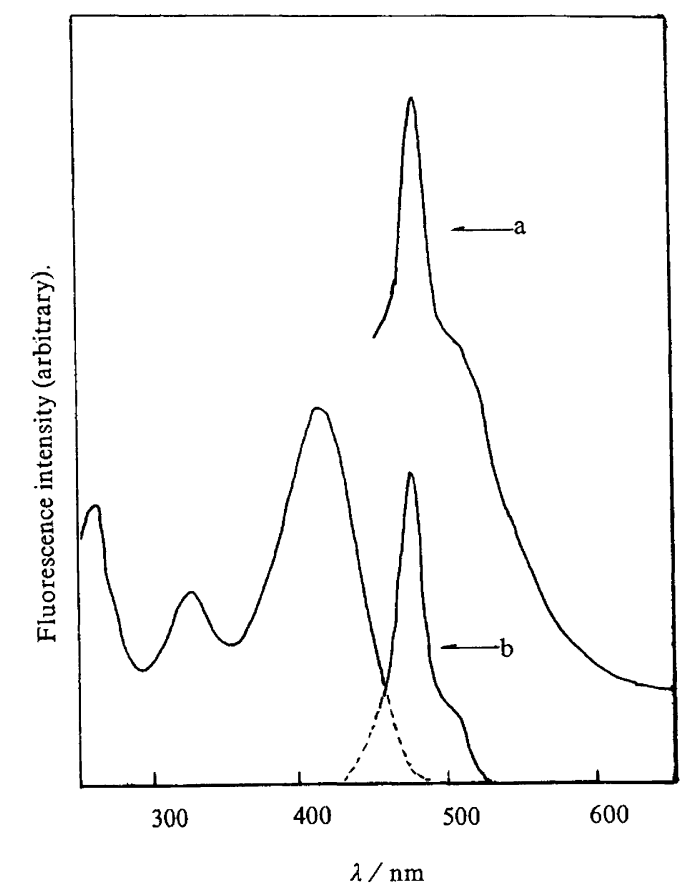

Fig. 3. Emission spectra of (TPP) $\mathrm{ClO}_{4}$ (a) $\left(2 \times 10^{-5}\right)$ and TPPM (b) $\left(1 \times 10^{-5} \mathrm{M}\right.$ ) (in DMF solution, $\lambda_{\mathrm{ex}}=417 \mathrm{~nm}$ ) at room temperature. The excitation spectrum of TPPM is given on the left-hand side.

fluorescence of TPP can be quenched by $\mathrm{Mo}_{6} \mathrm{O}_{19}{ }^{2-}$. The photochromism process and the quenching mechanism of TPPM may be summarized as follows: ${ }^{17}$

fluorescence:

$$
\mathrm{TPP}^{+} \stackrel{h \mathrm{v}}{\rightleftharpoons}\left(\mathrm{TPP}^{+}\right)^{*}
$$

quenching:

$\left(\mathrm{TPP}^{+}\right)^{*}+\mathrm{Mo}_{6} \mathrm{O}_{19}{ }^{2-} \rightarrow \mathrm{TPP}^{+\cdot}+\left(\mathrm{Mo}_{6} \mathrm{O}_{19}{ }^{2-}\right)^{*}$

photochromism:

$\left(\mathrm{TPP}^{+}\right)^{*}+\mathrm{SH}_{2} \rightarrow \mathrm{TPP}^{\cdot}+\mathrm{SH}_{2}^{+}$

The $\left(\mathrm{Mo}_{6} \mathrm{O}_{19}{ }^{2-}\right) *$ state in TPPM can be obtained by energy transfer with ultraviolet irradiation from excited $\left.(\mathbf{T P P})^{+}\right)^{*}$, which results in quenching of the fluorescence of $\left(\mathbf{T P P}^{+}\right)^{*}$. From the redox potentials of $\mathbf{T P P}^{+}$ $(-0.37 \mathrm{~V})^{18}$ and $\mathrm{Mo}_{6} \mathrm{O}_{19}{ }^{2-}(-0.83 \mathrm{~V}),{ }^{19}$ it can be expected that $\mathbf{T P P}{ }^{+}$may interact with $\mathrm{Mo}_{6} \mathrm{O}_{19}{ }^{3-}$ :

$\mathrm{Mo}_{6} \mathrm{O}_{19}{ }^{3-}+\mathrm{TPP}^{+} \rightarrow \mathrm{Mo}_{6} \mathrm{O}_{19}{ }^{2-}+\mathrm{TPP}$

Because the photochromism of TPP is reversible, ${ }^{17}$ the all photochromic procedures of TPPM are also reversible.

From the results outlined above, it can be expected that the quantum yield for the formation of the reduced hexamolybdate will increase by energy transfer from excited TPP. The fact that TPPM shows reversible photochromism and a faster fade rate may be due to interactions between the $\mathbf{T P P}{ }^{+}$radical and $\mathrm{Mo}_{6} \mathrm{O}_{19}{ }^{3-}$.

Structural studies. The atomic coordinates of non-hydrogen atoms, bond distances and angles are listed in Tables 1, 2 and 3, respectively. The molecular structure and crystal structure of the title complex are displayed in Figs. 4 and 5.

The average Mo-O bond distances in $\left[\mathrm{Mo}_{6} \mathrm{O}_{19}\right]^{2-}$ are similar to those reported previously, ${ }^{20,21}$ i.e. $1.680(6) \AA$ for $\mathrm{Mo}-\mathrm{O}_{\mathrm{t}}$ (terminal), 1.917(4) $\AA$ for $\mathrm{Mo}-\mathrm{O}_{\mathrm{b}}$ (bridging) and 2.312(1) $\AA$ for $\mathrm{Mo}_{\mathrm{c}} \mathrm{O}_{\mathrm{c}}$ (central).

The pyryllium ring is almost planar, with a maximum deviation of $0.018 \AA$ from the best plane. The bond angle of oxygen is $124.1(7)^{\circ}$ and the two $\mathrm{C}-\mathrm{O}$ bonds are

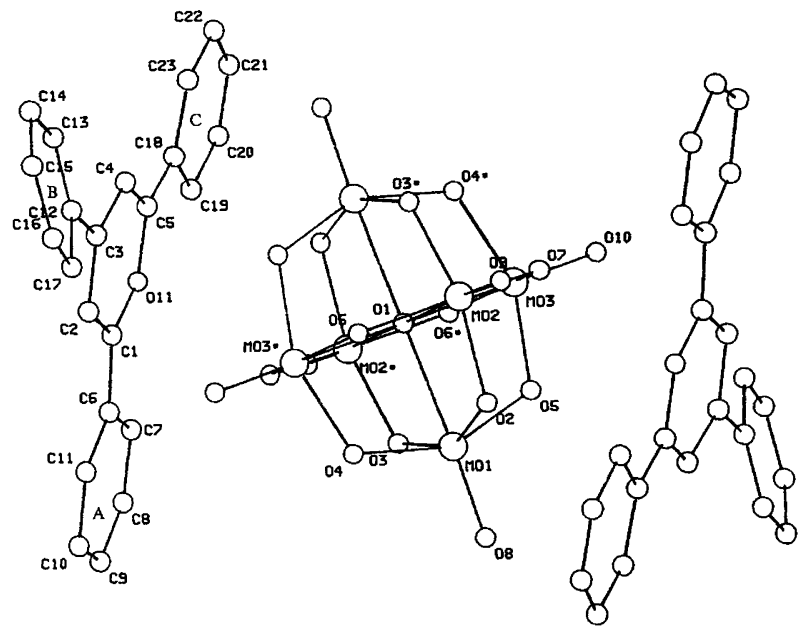

Fig. 4. Molecular structure of $[\mathrm{TPP}]_{2}\left[\mathrm{Mo}_{6} \mathrm{O}_{19}\right]$. 
Table 1. The non-hydrogen atomic coordinates of $[\mathrm{TPP}]_{2} \mathrm{Mo}_{6} \mathrm{O}_{19}$.

\begin{tabular}{lllll}
\hline Atom & $x$ & $y$ & $z$ & $B / A$ \\
\hline Mo1 & $0.23473(8)$ & $0.1149(1)$ & $0.5701(1)$ & $2.07(3)$ \\
Mo2 & $0.13609(7)$ & $0.2879(1)$ & $0.4961(1)$ & $1.99(3)^{a}$ \\
Mo3 & $0.27897(8)$ & $0.3296(1)$ & $0.6203(1)$ & $2.17(3)$ \\
O1 & 0.250 & 0.250 & 0.500 & $1.6(3)$ \\
O2 & $0.1459(5)$ & $0.1698(9)$ & $0.5523(8)$ & $1.7(3)^{a}$ \\
O3 & $0.3296(5)$ & $0.1110(9)$ & $0.5594(9)$ & $2.2(3)$ \\
O4 & $0.2146(7)$ & $0.0779(9)$ & $0.4582(9)$ & $2.6(3)$ \\
O5 & $0.2615(6)$ & $0.205(1)$ & $0.652(8)$ & $2.5(3)$ \\
O6 & $0.1341(5)$ & $0.217(1)$ & $0.3980(8)$ & $2.3(3)^{a}$ \\
O7 & $0.1826(5)$ & $0.344(1)$ & $0.5962(8)$ & $2.5(3)^{a}$ \\
O8 & $0.2243(7)$ & $0.015(1)$ & $0.618(1)$ & $3.8(4)$ \\
O9 & $0.0528(4)$ & $0.311(1)$ & $0.4944(9)$ & $3.2(3)$ \\
O10 & $0.29990(7)$ & $0.388(1)$ & $0.7082(9)$ & $3.8(4)$ \\
O11 & $0.4173(7)$ & $0.239(1)$ & $0.2943(9)$ & $3.1(3)$ \\
C1 & $0.382(1)$ & $0.166(2)$ & $0.260(1)$ & $2.6(4)$ \\
C2 & $0.324(1)$ & $0.184(2)$ & $0.2202(1)$ & $2.8(5)$ \\
C3 & $0.303(1)$ & $0.274(2)$ & $0.184(1)$ & $2.8(5)$ \\
C4 & $0.342(1)$ & $0.348(2)$ & $0.223(4)$ & $2.5(4)$ \\
C5 & $0.398(1)$ & $0.329(2)$ & $0.279(1)$ & $2.8(5)$ \\
C6 & $0.4067(8)$ & $0.076(2)$ & $0.286(1)$ & $2.3(4)^{a}$ \\
C7 & $0.467(8)$ & $0.065(2)$ & $0.343(2)$ & $4.2(6)^{a}$ \\
C8 & $0.492(1)$ & $-0.021(2)$ & $0.362(2)$ & $5.3(7)^{a}$ \\
C9 & $0.459(1)$ & $-0.100(2)$ & $0.334(2)$ & $5.3(7)$ \\
C10 & $0.400(2)$ & $-0.091(2)$ & $0.279(2)$ & $5.7(7)$ \\
C11 & $0.372(1)$ & $-0.004(2)$ & $0.2557(2)$ & $4.7(6)$ \\
C12 & $0.264(1)$ & $0.296(2)$ & $0.112(1)$ & $2.9(5)$ \\
C13 & $0.233(1)$ & $0.374(2)$ & $0.083(2)$ & $5.1(7)$ \\
C14 & $0.172(1)$ & $0.394(2)$ & $0.023(2)$ & $5.8(7)$ \\
C15 & $0.123(1)$ & $0.326(2)$ & $0.013(2)$ & $5.2(7)$ \\
C16 & $0.129(1)$ & $0.246(2)$ & $0.052(2)$ & $5.3(7)$ \\
C17 & $0.188(1)$ & $0.222(2)$ & $0.107(2)$ & $4.0(6)$ \\
C18 & $0.4439(9)$ & $0.399(2)$ & $0.320(1)$ & $2.3(4)$ \\
C19 & $0.501(1)$ & $0.369(2)$ & $0.373(2)$ & $4.8(62)$ \\
C20 & $0.545(1)$ & $0.443(2)$ & $0.412(2)$ & $6.1(8)$ \\
C21 & $0.531(1)$ & $0.529(2)$ & $0.401(2)$ & $5.0(6)$ \\
C22 & $0.475(2)$ & $0.560(2)$ & $0.350(2)$ & $5.7(8)$ \\
C23 & $0.420(1)$ & $0.493(2)$ & $0.311(2)$ & $4.0(6)$ \\
\hline & & & & \\
\hline & & & & \\
& & &
\end{tabular}

${ }^{a}$ Isotropic thermal factors.

$1.338(8)$ and $1.356(8) \AA$, respectively, which differ from that of the TPP-tetracyanopropenide (TPP-TCP) ${ }^{22}$ $\left[122.5(3)^{\circ}\right.$ and $\left.1.355(4) \AA\right]$. The $\mathrm{C}-\mathrm{C}$ bond lengths of pyryllium ring are in the accepted range for a benzene
Table 3. Bond angles of $[\mathrm{TTP}]_{2} \mathrm{Mo}_{6} \mathrm{O}_{19}$ (in ${ }^{\circ}$ ).

\begin{tabular}{|c|c|c|c|}
\hline O1-Mo1-O2 & $76.8(2)$ & O5-Mo3-O10 & $104.1(3)$ \\
\hline O 1-Mo1-O3 & $71.1(2)$ & O6-Mo3-07 & $154.3(2)$ \\
\hline O1-Mo 1-O4 & $75.8(1)$ & O6-Mo3-010 & $103.6(2)$ \\
\hline 01-Mo1-05 & $76.1(1)$ & O7-Mo3-010 & $102.1(2)$ \\
\hline O1-Mo1-08 & $178.2(2)$ & C1-011-C5 & $124.1(7)$ \\
\hline $\mathrm{O} 2-\mathrm{Mo} 1-\mathrm{O} 3$ & $152.9(3)$ & $\mathrm{O} 11-\mathrm{C} 1-\mathrm{C} 2$ & $117.8(5)$ \\
\hline O2-Mo 1-O4 & $86.1(2)$ & $\mathrm{O} 11-\mathrm{C} 1-\mathrm{C} 6$ & $117.1(7)$ \\
\hline O2-Mo1-O5 & $88.1(2)$ & $\mathrm{C} 2-\mathrm{C} 1-\mathrm{C} 6$ & $125.0(6)$ \\
\hline O2-Mo1-08 & $104.1(3)$ & $\mathrm{C} 1-\mathrm{C} 2-\mathrm{C} 3$ & $120.2(6)$ \\
\hline O3-Mo 1-O4 & $86.5(2)$ & C2-C3-C4 & $118.7(7)$ \\
\hline O3-Mo1-O5 & $86.3(2)$ & $\mathrm{C} 2-\mathrm{C} 3-\mathrm{C} 12$ & $120.2(6)$ \\
\hline O3-Mo1-O8 & $103.0(2)$ & $\mathrm{C} 4-\mathrm{C} 3-\mathrm{C} 12$ & $121.1(6)$ \\
\hline O4-Mo 1-O5 & $151.9(2)$ & C3-C4-C5 & $120.0(6)$ \\
\hline O4-Mo1-08 & $102.5(3)$ & O11-C5-C4 & $119.2(8)$ \\
\hline 05-Mo1-08 & $105.6(3)$ & O11-C5-C18 & $116(1)$ \\
\hline $\mathrm{O} 1-\mathrm{Mo} 2-\mathrm{O} 2$ & $76.5(3)$ & $\mathrm{C} 4-\mathrm{C} 5-\mathrm{C} 8$ & $124.3(7)$ \\
\hline $\mathrm{O} 1-\mathrm{Mo} 2-\mathrm{O} 3$ & $76.5(3)$ & $\mathrm{C} 1-\mathrm{C} 6-\mathrm{C} 7$ & $120.8(7)$ \\
\hline O1-Mo2-06 & $77.04(9)$ & $\mathrm{C} 1-\mathrm{C} 6-\mathrm{C} 11$ & $121.7(8)$ \\
\hline O1-Mo2-07 & $76.1(2)$ & $\mathrm{C} 7-\mathrm{C} 6-\mathrm{C} 11$ & $117.7(6)$ \\
\hline O1-Mo2-09 & $177.8(1)$ & $\mathrm{C} 6-\mathrm{C} 7-\mathrm{C}$ & $119.4(7)$ \\
\hline $\mathrm{O} 2-\mathrm{Mo} 2-\mathrm{O} 3$ & $152.9(4)$ & $\mathrm{C} 7-\mathrm{C} 8-\mathrm{C} 9$ & $123.4(8)$ \\
\hline $\mathrm{O} 2-\mathrm{Mo} 2-06$ & $86.8(2)$ & $\mathrm{C} 8-\mathrm{C} 9-\mathrm{C} 10$ & $118.2(7)$ \\
\hline $\mathrm{O} 2-\mathrm{Mo} 2-07$ & $86.7(2)$ & $\mathrm{C} 9-\mathrm{C} 10-\mathrm{C} 11$ & $120.6(7)$ \\
\hline O2-Mo2-09 & $101.4(2)$ & $\mathrm{C} 6-\mathrm{C} 11-\mathrm{C} 10$ & $3(7)$ \\
\hline O3-Mo2-06 & $86.3(2)$ & C3-C12-C13 & $121.7(8)$ \\
\hline $\mathrm{O} 3-\mathrm{Mo} 2-\mathrm{O} 7$ & $87.7(2)$ & C3-C12-C17 & $118.3(7)$ \\
\hline $\mathrm{O} 3-\mathrm{Mo2}-09$ & $105.8(3)$ & C13-C12-C17 & $119.9(8)$ \\
\hline $\mathrm{O} 6-\mathrm{Mo} 2-\mathrm{O} 7$ & $153.2(2)$ & C12-C13-C14 & $123(2)$ \\
\hline O6-Mo2-09 & $102.5(2)$ & C13-C14-C15 & $115(2)$ \\
\hline 07-Mo2-09 & $104.3(2)$ & C14-C15-C16 & $123(2)$ \\
\hline O1-Mo3-O4 & $76.6(1)$ & C15-C16-C17 & 123.1(9) \\
\hline O1-Mo3-O5 & $75.8(1)$ & $\mathrm{C}_{12-C} 17-\mathrm{C} 16$ & $115.3(7)$ \\
\hline & $77.3(1)$ & C5-C $18-C 19$ & $117.5(9)$ \\
\hline Mo3-07 & $77.2(1)$ & $\mathrm{C} 5-\mathrm{C} 18-\mathrm{C} 23$ & $122.0(9)$ \\
\hline Mo3-010 & $179.2(2)$ & C19-C18-C23 & $120(1)$ \\
\hline O4-Mo3-O5 & $152.5(2)$ & C18-C29-C20 & $114.9(9)$ \\
\hline O4-Mo3-06 & $87.8(2)$ & C19-C20-C21 & $122.5(9)$ \\
\hline & $87.8(2)$ & $\mathrm{C} 2 \mathrm{O}-\mathrm{C} 21-\mathrm{C} 22$ & $124(1)$ \\
\hline O4-Mo3-010 & $103.5(2)$ & C21-C22-C23 & $116.6(8)$ \\
\hline 05 & $85.9(1)$ & C18-C23-C22 & $121.6(8)$ \\
\hline 05 & $86.3(2)$ & & \\
\hline
\end{tabular}

ring, which is different from the of TPP-TCP, where the $\mathrm{C}-\mathrm{C}$ bond lengths are significantly different from that of a benzene ring. This indicates that the electron delocalization of the pyryllium ring in TPPM is greater than that of TPP-TCP. The electron delocalization may also be

Table 2. Bond distances of $[\mathrm{TTP}]_{2} \mathrm{Mo}_{6} \mathrm{O}_{19}$ (in $\AA$ ).

\begin{tabular}{|c|c|c|c|c|c|}
\hline Mo1-01 & $2.3178(7)$ & Mo3-06 & $1.918(4)$ & $\mathrm{C8}-\mathrm{Cg}$ & $1.34(2)$ \\
\hline Mo1-O2 & $1.901(7)$ & Mo3-O7 & $1.889(7)$ & $\mathrm{C} 9-\mathrm{C} 10$ & $1.36(2)$ \\
\hline Mo1-O3 & $1.92(1)$ & Mo3-010 & $1.668(7)$ & C10-C11 & $1.39(1)$ \\
\hline Mo1-O4 & $1.935(3)$ & $\mathrm{O} 11-\mathrm{C} 1$ & $1.338(8)$ & C 12-C13 & $1.33(1)$ \\
\hline Mo1-O5 & $1.897(3)$ & O11-C5 & $1.356(9)$ & C12-C17 & $1.46(1)$ \\
\hline Mo1-08 & $1.676(4)$ & $\mathrm{C} 1-\mathrm{C} 2$ & $1.40(1)$ & C13-C14 & $1.44(1)$ \\
\hline Mo2-01 & $2.3064(6)$ & $\mathrm{C} 1-\mathrm{C} 6$ & $1.432(9)$ & C14-C15 & $1.38(2)$ \\
\hline Mo2-O2 & $1.935(5)$ & $\mathrm{C} 2-\mathrm{C} 3$ & $1.388(7)$ & C 15-C 16 & $1.32(2)$ \\
\hline Mo2-O3 & $1.913(6)$ & C3-C4 & $1.410(9)$ & C16-C17 & $1.40(1)$ \\
\hline Mo2-06 & $1.936(4)$ & C3-C 12 & $1.48(1)$ & C18-C19 & $1.39(2)$ \\
\hline Mo2-O7 & $1.950(4)$ & $\mathrm{C} 4-\mathrm{C} 5$ & $1.36(1)$ & C18-C23 & $1.37(1)$ \\
\hline Mo2-09 & $1.676(6)$ & C5-C18 & $1.44(1)$ & C19-C20 & $1.46(2)$ \\
\hline Mo3-01 & $2.3127(5)$ & $\mathrm{C} 6-\mathrm{C} 7$ & $1.40(1)$ & C2O-C21 & $1.27(1)$ \\
\hline Mo3-O4 & $1.895(4)$ & C6-C11 & $1.38(2)$ & C21-C22 & $1.36(1)$ \\
\hline Mo3-O5 & $1.920(4)$ & $\mathrm{C} 7-\mathrm{C} 8$ & $1.36(2)$ & C22-C23 & $1.41(1)$ \\
\hline
\end{tabular}




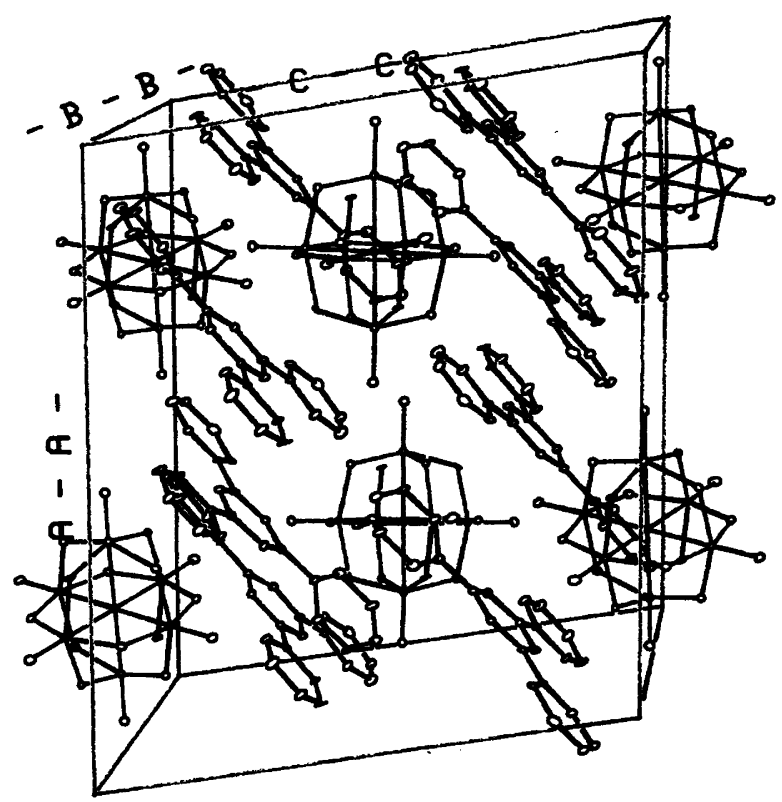

Fig. 5. View of crystal structure of $[\mathrm{TPP}]_{2} \mathrm{Mo}_{6} \mathrm{O}_{19}$.

explained by $\mathrm{C}-\mathrm{C}$ bond lengths and angles connecting the benzene rings with pyryllium. The two $\mathrm{C}-\mathrm{C}$ bond lengths neighbouring the $\mathrm{O}$ atom are 1.43 and $1.44 \AA$, and are shorter than the equivalent bonds in TPP-TCP. The angles $\mathrm{O}(11)-\mathrm{C}(1)-\mathrm{C}(6)$ and $\mathrm{O}(11)-\mathrm{C}(5)-\mathrm{C}(18)$ [117.1(7) and $\left.116(1)^{\circ}\right]$, close to $120^{\circ}$, are larger than that of TPP-TCP $\left(113.6\right.$ and $\left.113.3^{\circ}\right)$. The three benzene rings are planar within experimental error, and the rings of $\mathrm{A}$ and $\mathrm{C}$ are coplanar with the pyryllium ring. Ring $\mathrm{B}$ tilts from the plane of pyryllium at angles of $2.85,25.25$ and $3.14^{\circ}$ for rings A, B and C, respectively. The results indicate that the pyryllium ring in TPPM tends to form a conjugated structure with two ortho benzene rings, and the electron deficit at $C(1)$ and $C(5)$ is higher than that at $\mathrm{C}(3)$.

In the unit cell, $\mathrm{Mo}_{6} \mathrm{O}_{19}{ }^{2-}$ and TPP are arranged in the form of parallel columns along the $c$-axis. The cations and anions stack alternately. The anions stack along the $\boldsymbol{a}$-axis, and the cations along the $\boldsymbol{a}$-direction inclining to the $c$-axis. In the column, although the TPP cation is sandwiched by anions and vice versa, the TPP cation is alternately parallel in order, and its positive charge is in closer contact with one of the anions than the other. Thus the TPP cation and $\mathrm{Mo}_{6} \mathrm{O}_{19}{ }^{2-}$ anion can be considered to form an ion-pair in the crystal as a column unit.

Acknowledgements. This work is supported by a grant for key research project from the State Science and Technology Commission and National Natura Science Foundation of China.

\section{References}

1. Ohashi, Y., Yanagi, K., Sasads, Y. and Yamase, T. Bull. Chem. Soc. Jpn. 55 (1982) 1254 and references therein.

2. Prosser-Mccartha, C. M., Kadkhodayan, M., Williamson, M. M., Bouchard, D. A. and Hill, C. L. J. Chem. Soc., Chem. Commun. (1986) 1747.

3. Williamson, M. M., Bouchard, D. A. and Hill, C. L. Inorg. Chem. 26 (1987) 1436.

4. Hill, C. L., Bouchard, D. A., Kadkhodayan, M., Williamson, M. M., Schmidt, J. A. and Hilinski, E. F. J. Am. Chem. Soc. 110 (1988) 5471.

5. Attanasio, D., Bonamico, M., Fares, V., Imperatori, P. and Suber, L. J. Chem. Soc., Dalton Trans. (1990) 3221.

6. Attanasio, D., Bonamico, M., Fares, V. and Suber, L. J. Chem. Soc., Dalton Trans. (1992) 2523.

7. Xu, X.-X., You, X.-Z. and Wang, X. Polyhedron 13 (1994) 1011.

8. Pope, M. T. and Muller, A. Angew. Chem., Int. Ed. Engl. 30 (1991) 34.

9. Launay, J. P. J. Inorg. Nucl. Chem. 38 (1976) 807.

10. Pope, M. T. Heteropoly and Isopoly Oxometalates, Springer, Berlin 1983.

11. Kraut, B. and Ferraudi, G. J. Chem. Soc., Dalton Trans. (1991) 2063.

12. Che, M., Fournier, M. and Launay, T. P. J. Chem. Phys. 71 (1979) 1954.

13. Simalty, M. Bull. Soc. Chim. Fr. (1965) 1944.

14. Frenz, B. A. in Schenk, H., Olthof-Hazekamp, R., Vankoningsveld, H. and Bassi, G. C., eds., Computing in Crystallography, Delft University Press, Delft 19, pp. 64-71.

15. Fukutomi, H., Harazono, T. and Kojima, T. Bull. Chem. Soc. Jpn. 59 (1986) 2387.

16. Wintgens, V., Pouliguen, J., Valt, P., Kossanyi, J., Canonica, S. and Wild, U. P. Chem. Phys. Lett. 123 (1986) 735.

17. Miranda, M. A. and Garcia, H. Chem. Rev. 94 (1994) 1063.

18. Fragst, F. and Ziebig, R. Electrochim. Acta 23 (1978) 735.

19. Chen, Q. and Zubieta, J. Coord. Chem. Rev. 114 (1992) 107.

20. Fuchs, S., Fretwald, W. and Hartl, H. Acta Crystallogr., Sect. B 34 (1978) 1764.

21. Clegg, W. and Sheldrick, G. M. Acta Crystallogr., Sect. B (1982) 2906.

22. Tamamura, T., Yamane, T., Yasuoka, N. and Kasai, N. Bull. Chem. Soc. Jpn. 47 (1974) 832.

Received December 30, 1994. 